\title{
Determination of the Factors Affecting Sleep Quality in the General Population During the Early Phase of the COVID-19 Pandemic
}

\section{COVID-19 Salgını Erken Dönemlerinde Genel Popülasyonda Uyku Kalitesini Etkileyen Etmenlerin Belirlenmesi}

\author{
(D) Yeliz Akkuş, (D) Süleyman Şahin*, (D) Yalçın Kanbay**, (D) Ali Alpkaan Ünlü*** \\ Kafkas University Faculty of Health Sciences, Department of Medical Nursing, Kars, Turkey \\ *Kafkas University Health Sciences Faculty, Department of Public Health Nursing, Kars, Turkey \\ **Artvin Çoruh University Faculty of Health Sciences, Department of Psychiatric Nursing, Artvin, Turkey \\ ***Kocaali State Hospital, Clinic of Emergency Medicine, Kocaeli, Turkey
}

\begin{abstract}
Objective: This study aimed to determine the factors affecting sleep quality in the general population during the early phase of the Coronavirus disease-2019 (COVID-19) pandemic.

Materials and Methods: This was a cross-sectional study and included 595 people who were surveyed online. The data were collected through the "socio-demographic characteristics form", "Pittsburgh Sleep Quality index" and "Generalized Anxiety Disorder scale-7".

Results: In this study, sleep quality among individuals was found to be poor, and as the level of generalised anxiety increased, sleep quality decreased. Sleep quality was found to be poor those living in urban areas and those with chronic diseases.

Conclusion: The results of the study can be used to develop therapeutic strategies and implement social policies to support people with sleep difficulties.

Keywords: COVID-19, sleep quality, GAD-7
\end{abstract}

Öz

Amaç: Bu çalışma Koronavirüs hastalığı-2019 (COVID-19) salgını erken dönemlerinde genel popülasyonda uyku kalitesini etkileyen etmenlerin belirlenmesi amacı ile planlanmıştır.

Gereç ve Yöntem: Bu çalışma kesitsel tipte olup "online survey" (çevrimiçi anket) ile ulaşılan 595 kişi ile tamamlanmıştır. Veriler "sosyodemografik özellikler formu", "Pittsburgh Uyku Kalitesi indeksi", "Yaygın Anksiyete Bozukluğu ölçeği-7" ile toplanmıştır.

Bulgular: Bu çalışmada bireylerin uyku kalitesi kötü olup, yaygın anksiyete düzeyi arttıkça uyku kalitesi azalmaktadır. Kentsel bölgede yaşayanlarda ve kronik hastalığı olanlarda uyku kalitesi kötü bulunmuştur.

Sonuç: Sonuçlar, bu süreçte uyku güçlüğü çeken bireyleri desteklemek için terapötik stratejilerin geliştirilmesi ve sosyal politikaların uygulanması için kullanılabilir.

Anahtar Kelimeler: COVID-19, uyku kalitesi, GAD-7

\section{Introduction}

In December 2019, a disease began to spread rapidly after a new Coronavirus disease-2019 (COVID-19) was revealed leading to a highly contagious Severe Acute Respiratory syndrome (SARSCoV-2) in Wuhan, China. On March 11 th, 2020 , the World Health Organization declared COVID-19 as a pandemic (1) and as of February $19^{\text {th }}, 2021,110,430.962$ deaths were detected worldwide. In Turkey, a total of 2,616.600 COVID-19 cases were confirmed and 27.821 individuals died from the disease (2).

Human-to-human transmission of the virus was confirmed after the first COVID-19 case in December 2019 and during this process, it was determined that asymptomatic individuals could also transmit COVID-19 virus. Rules and restrictions such as staying at home and isolating oneself, washing hands frequently with soap and wearing masks in public areas mandatorily, were started to be imposed in order to reduce

Address for Correspondence/Yazışma Adresi: Assoc. Prof. Yeliz Akkuş, Kafkas University Faculty of Health Sciences, Department of Medical Nursing, Kars, Turkey Phone: +90 5052598458 E-mail: yelizakkus@gmail.com ORCID-ID: orcid.org/0000-0002-9321-2357

Received/Geliş Tarihi: 18.01.2021 Accepted/Kabul Tarihi: 28.02.2021

${ }^{\circ}$ Copyright 2021 by Turkish Sleep Medicine Society / Journal of Turkish Sleep Medicine published by Galenos Publishing House. 
contact as much as possible. All these restrictions completely changed the daily lives of individuals. Not leaving home unless necessary, continuing the education of school-age children at home, reducing social interaction, being unable to go to work and working from home or not continuing to work, working for more hours under stressful conditions, protecting the health of oneself and the individuals around caused stress, anxiety and sleep problems in individuals (3).

The number of deaths due to COVID-19 is still increasing, and the spread of the virus has not been fully controlled yet. The socio-economic impacts of COVID-19 have emerged, and it is unknown how long it will last. While the studies on COVID19 continue, there are also uncertainties (4). In addition, it is known that anxiety of individuals under quarantine increases in case of uncertainty $(5,6)$.

During epidemics, individuals often experience various psychological difficulties such as collective fear, panic and phobia (7). In studies examining the psychological effect of previous pandemics (e.g. SARS), 35\% of individuals recovering from SARS reported moderate to severe depression and/or anxiety (8). When the COVID-19 pandemic was compared with SARS based on the current findings, the effect of COVID-19 was found to be greater, and to continue in the future (9). COVID19 anxiety has four main grounds: body, important individuals, uncertainty and action/inaction (10). Therefore, studies were started to be conducted all over the world in order to determine the effect of COVID-19 on the psychological state of individuals. Anxiety is a feeling of fear and worry that is difficult to define. This feeling may be accompanied by certain sensations in the body (11). Generalized anxiety disorder (GAD) is characterized by unrealistic, excessive anxiety about living conditions that is not proportional to actual problems (12). Fear, anxiety, GAD and depression of individuals were found to increase during the COVID-19 pandemic, as studies showed $(13,14)$. In their study conducted with 451 individuals, Çıtak and Pekdemir (14) stated that anxiety was very high in Turkish society. Ekiz et al. (15) stated that the level of anxiety in the society due to COVID19 was moderate. During COVID-19, mental health problems affected not only society but also healthcare professionals (16). Enough sleep is very important to cope with anxiety. However, it is known that individuals' sleep patterns are disrupted during stressful periods such as epidemics $(17,18)$. Lauriola et al. (19) stated that intolerance to uncertainty and anxiety was associated with personal sleep problems. In Italy, it was stated that insomnia, sleep loss and poor sleep quality emerged in the individuals who had to stay home during COVID-19 pandemic (20). A web-based survey $(n=603)$ in China found $18.1 \%$ of the respondents reported poor sleep quality during the COVID19 outbreak (21). In addition, the sleep quality of healthcare professionals, was found to be worse. In another study, individuals with sleep disorders were found to experience more cardiovascular events (22). Therefore, it is important to evaluate the sleep quality of individuals living in the society and other affecting factors during the COVID-19 pandemic.

When the studies conducted in Turkey are examined, it is seen that the number of the studies conducted on sleep and the factors affecting sleep during COVID-19 pandemic is limited, and there is no study conducted in the Eastern Anatolian Region of Turkey. Therefore, this study was carried out.

\section{Materials and Methods}

Aim: This study was planned to determine the factors affecting sleep quality in the general population during the early phase of the COVID-19 pandemic.

Research type: This is a cross-sectional study.

Research sample: Snowball sampling method was used for the sample selection in the study. In snowball sampling, one of the units belonging to the universe is contacted first. With the help of the contacted unit, the second unit is reached, and the third unit is reached with the help of the second unit. In this way, the sample is grown like rolling a snowball (23). For this purpose, individuals were reached, and data were collected through online applications (WhatsApp) (24). A web address was used to provide detailed information about the survey, to avoid resampling and to check the internet protocol address. Individuals, who met the inclusion criteria in sample selection, were included in the study. The inclusion criteria in the study were determined as living in the Eastern Anatolian Region, being at 18 to 65 years of age, being literate and willing to participate in the study. In line with these criteria, 595 individuals, who could be reached within three months as of May 6, 2020, constituted the sample of the study.

Data collection tools: "Socio-demographic characteristics form", "Pittsburgh Sleep Quality index (PSQI)" and "GAD scale-7" were used in the study.

Socio-demographic characteristics form: Socio-demographic characteristics consist of variables such as age, gender, occupation, marital status, the number of individuals they live with, the presence of chronic diseases, the hours spent outside, the presence of a healthcare professional relative, whether the measures taken against COVID-19 are sufficient or not.

PSQI: PSQI was developed by Buysse et al. and adapted into Turkish by Ağargün and Kara (25) PSQI is a 19-article selfreport scale that evaluates sleep quality and disorder within the last one month. It consists of 24 questions, 19 of them are self-report questions, 5 of them are questions to be answered by the spouse or roommate (26). The scored 19 questions of the scale consist of 7 components. These are subjective sleep quality, sleep latency, sleep duration, sleep efficiency, sleep disturbance, use of sleep medication and daytime dysfunction. Each component is evaluated with a score of 0 to 3 . The total score of 7 components gives the total score of the scale. The total score ranges between $0-21$. A total score greater than 5 indicates "poor sleep quality".

Generalized anxiety disorder-7: GAD-7 is a short self-report test that evaluates GAD and was developed according to DSMIV-TR criteria by Spitzer et al. (27). The GAD-7 scale measures GAD according to DSM IVTR criteria. GAD-7 is a Self-assessment scale (28). The four (0-3) point Likert-type scale $(0=$ not at all, $1=$ several days, $2=$ =more than half the days, $3=$ nearly every day) measures the 7 items of GAD-7. The score that can be obtained from the scale is between 0 and 21 (28). 
Scale scores: 0-4 was evaluated as mild anxiety, 5-9 moderate, 10-14 high and 15-21 severe. The cut-off value of 8 for the GAD-7 total score was determined as the threshold value for the possible GAD diagnosis. The Cronbach's alpha reliability coefficient of the scale for this study was calculated as 0.93 .

Data collection: Due to the pandemic period experienced in our country and in the world, the data were collected online in order to prevent the transmission. For this purpose, social media platforms such as Facebook and Instagram and online applications such as WhatsApp were used. The access link of the online survey prepared for data collection was sent to the participants, and the individuals were asked to answer the question forms.

\section{Statistical Analysis}

SPSS 23 (IL, Chicago, USA) was used for the descriptive statistics in the study, and AMOS 23 statistical programs was used for the structural equation modelling. The obtained data were first examined in terms of extreme data, and necessary corrections were made. Then, the normal distribution features of the data set were examined, and it was observed that it provided the normal distribution.

Ethical issues: This study was carried out in accordance with the principles of Helsinki Declaration. Before the study, permission was obtained from the Ethics Committee of the Faculty of Health Sciences (date: May 6 ${ }^{\text {th }}, 2020$ and issue: 818295502.903/29) and the Ministry of Health. The confidentiality of the data to be used in the study was guaranteed. The purpose and importance of the study were explained to all individuals participating in the study, and the study was completed after their written consents were obtained.

\section{Results}

$66.4 \%$ of the individuals participating in the study were female, $71.2 \%$ were single, $91.2 \%$ were university graduates, $90.9 \%$ had social security, $54.3 \%$ had a regular job, $12.1 \%$ had chronic diseases, $66.9 \%$ lived in the city, $18.4 \%$ never consumed caffeine, $76.3 \%$ were smokers, and $13.3 \%$ consumed alcohol. The mean age of the sample was calculated as $27.9 \pm 7.1$, and the number of individuals in the household as $3.8 \pm 1.9$ (Table 1). The mean PSQI of the sample was calculated as $13.6 \pm 2.860$, and the mean GAD-7 score as $7.4 \pm 5.551$ (Table 2). The mean GAD-7 score of $42.7 \%$ of the individuals participating in the study was above 8 .

The measurement model of the 7-component structure of PSQI was examined with the first-level CFA, and it was found that this structure had sufficient significant values in explaining the sleep quality of the sample. When the values regarding the model were examined, although the factor loads of the components of "sleep duration", "sleep efficiency" and "use of sleep medication" were below 0.50 , the other components were found to have a value above 0.50 . Besides, the components were found to have significant standardized regression coefficients and $p$ values to

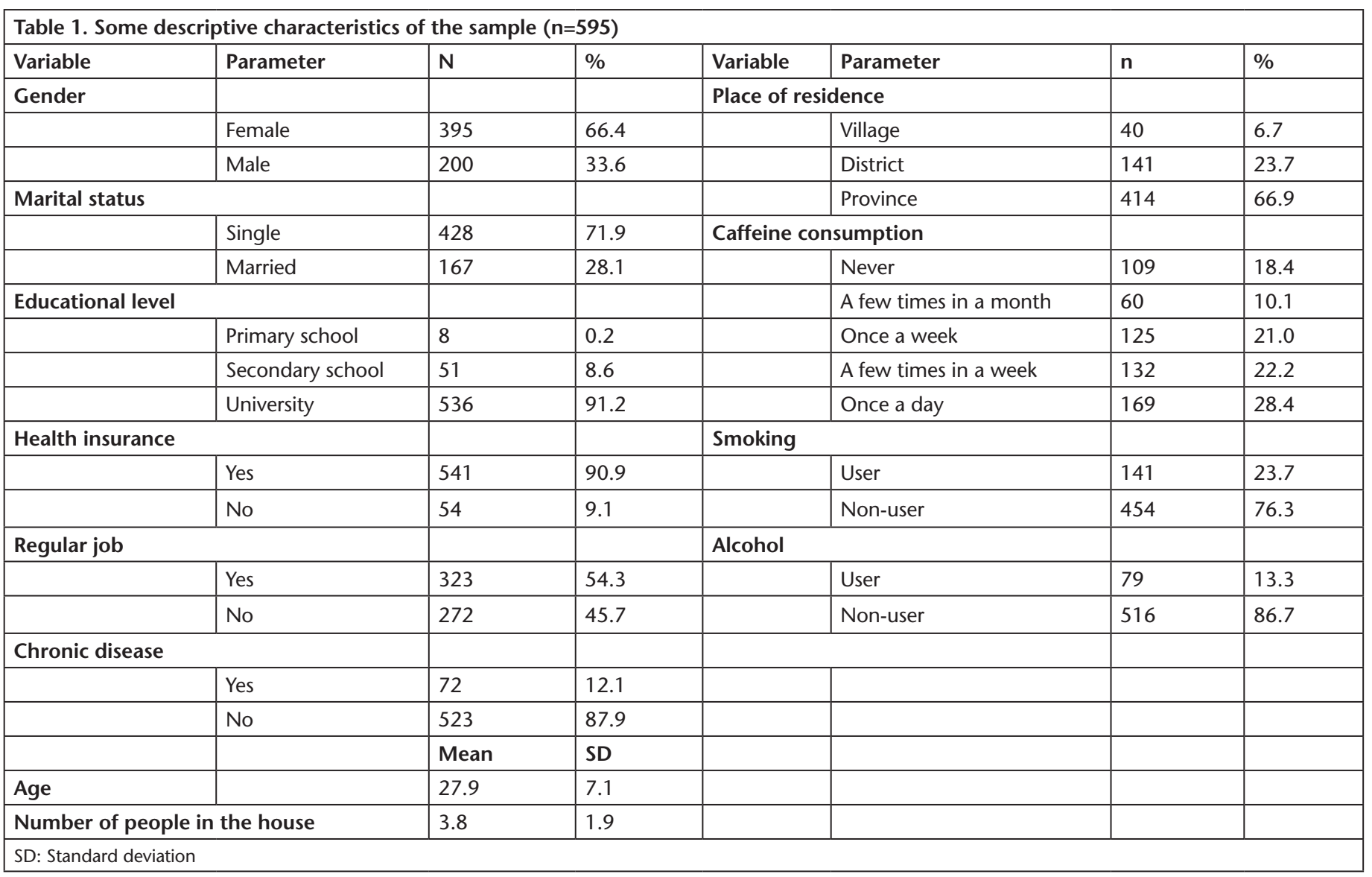


explain the implicit variable of sleep quality (subjective sleep quality $=0.776$ and $p<0.001$, sleep latency $=0.544$ and $p<0.001$, sleep duration $=0.275$ and $p<0.001$, sleep efficiency $=0.180$ and $p<0.05$, sleep disturbance $=0.520$ and $p<0.001$, use of sleep medication $=0.218$ and $p<0.001$, daytime dysfunction $=0.637$ and $p<0.001)$. In addition, when the fit indices of the model were examined, all statistics were found to be within the acceptable limits (CMIN/DF=1.39, GFI=0.99, $C F I=0.99$, $\mathrm{NFI}=0.97, \mathrm{TLI}=0.98, \mathrm{CFI}=0.99$ and $\mathrm{RMSEA}=0.02$ ) (Figure 1).

The structure of the GAD-7 scale, which consists of a single dimension and 7 items, was tested with the first-level single factor CFA, and the maximum likelihood calculation method was used. The factor loads of the scale items ranged between 0.76 and 0.83 , and the fit indices of the scale were examined by including all items in the original of the scale in the analysis. According to the results, the fit indices in the GAD-7 scale were determined as $\chi^{2}=37.58, \chi^{2} / \mathrm{df}=2.891, \mathrm{NFI}=0.99, \mathrm{TLI}=0.99$, $\mathrm{CFI}=0.99, \mathrm{GFI}=0.98, \mathrm{AGFI}=0.96, \mathrm{RMSEA}=0.05, \mathrm{RMR}=0.01$. It was determined that the goodness of fit values obtained as a result of the first-level CFA showed perfect fit with the proposed one-factor structure of the model. These results showed that the data obtained from the study were compatible with the predicted theoretical structure of the GAD-7 scale (Figure 1). In order to estimate the factors affecting sleep quality, an initial structural equation model was established, and the goodness of fit values of this model were examined. Variables such as age, gender, marital status, number of people in the household, educational status, regular job, place of residence, health insurance, smoking status, alcohol use status, caffeine

\begin{tabular}{|c|c|c|c|c|c|}
\hline Scales & $\mathbf{n}$ & Min & Max & $x$ & Stn. \\
\hline PSQI & \multirow{3}{*}{595} & 6 & 21 & 13.6 & 2.860 \\
\hline & & - & - & - & - \\
\hline GAD-7 & & 0 & 21 & 7.4 & 5.551 \\
\hline
\end{tabular}

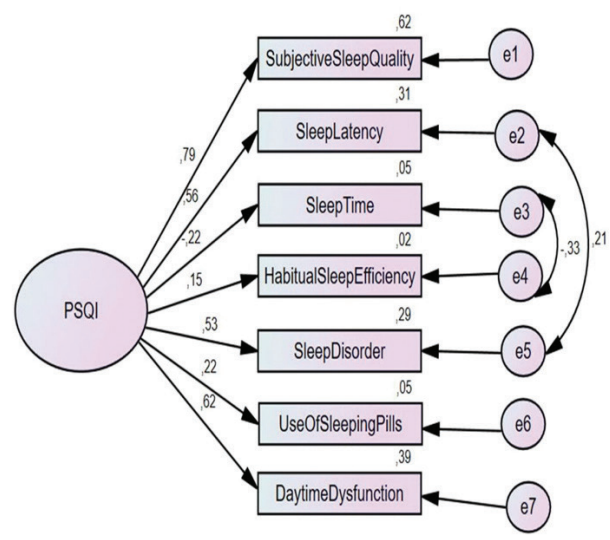

Figure 1. Path diagram of the PSQI and GAD-7 measurement model PSQI: Pittsburgh Sleep Quality index, GAD: Generalized anxiety disorder consumption, presence of chronic disease and GAD-7 scale mean score belonging to the sample were added to the model. When the goodness of fit values of the model were examined $\left(\chi^{2}=1311.14, \chi^{2} / \mathrm{df}=4.45, \mathrm{NFI}=0.74, \mathrm{TLI}=0.76\right.$, $\mathrm{CFI}=0.79, \mathrm{GFI}=0.85, \mathrm{AGFI}=0.82, \mathrm{RMSEA}=0.08, \mathrm{RMR}=0.27$ ), it was observed that the values were not at the desired level (Figure 2). Therefore, the standardized regression coefficients of the model were examined in order to obtain a better model. When the standardized regression weights of the variables included in the initial estimation model and the significance of their contribution to the model were examined, the variables of "age", "gender", "marital status", "number of individuals in the household", "educational level", "regular job", "health insurance", "smoking and alcohol use" and "caffeine consumption" did not show a significant relationship with the model $(p>0.05)$. In addition, the goodness of fit values of the initial structural model as a whole were not at an acceptable level. Therefore, in order to obtain a model with higher goodness of fit values or to increase the fit of the model to the data set, parameters that did not show a significant relationship with the model were removed from the analysis, and a new structural model was created (Table 3).

When the revised model estimating the factors affecting sleep quality and the goodness of fit values were examined, goodness of fit values of the model were found to be at acceptable levels $\left(\chi^{2}=198.61, \chi^{2} / \mathrm{df}=1.986, \mathrm{NFI}=0.95, \mathrm{TLI}=0.97\right.$, $\mathrm{CFI}=0.97, \mathrm{GFI}=0.96, \mathrm{AGFI}=0.95, \mathrm{RMSEA}=0.04, \mathrm{RMR}=0.03$ ), and the final version of the model was created. It was determined that parameters of "GAD-7" $(\mathrm{t}=14.279, \mathrm{p}<0.000)$, "place of residence" ( $\mathrm{t}=-3.065, \mathrm{p}<0.05)$ and "chronic disease" $(\mathrm{t}=-2.023$, $\mathrm{p}<0.05)$ included in the model, were found to have a significant effect on sleep quality (Figure 3). GAD-7 scale, one of the parameters of the revised model estimating sleep quality, was determined as a variable that had a significant effect on sleep quality. According to this result, as the GAD levels of individuals increased, their sleep quality decreased. The contribution of the GAD-7 parameter to the model was calculated as $72 \%$. The sleep quality of individuals living in rural areas was found

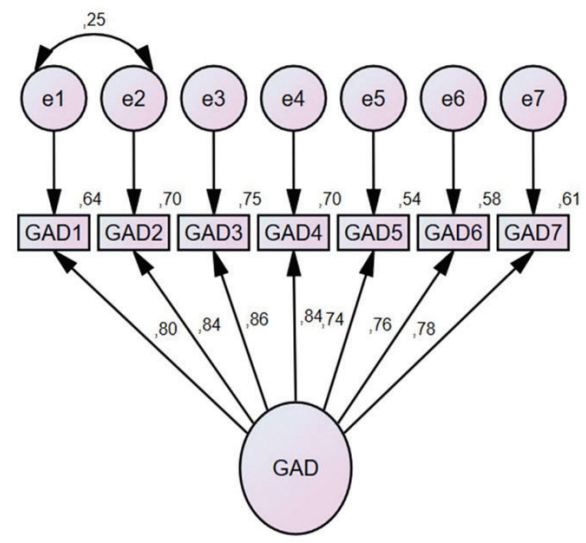


to be higher than those living in central residential areas. The presence of chronic disease was identified as another factor affecting sleep quality. According to the model obtained, the sleep quality of individuals with chronic disease was found to be lower than those without chronic disease. According to this model, it was determined that the variables that were included in the model and had significant standardized regression coefficients could explain 54\% of sleep quality (Figure 3).

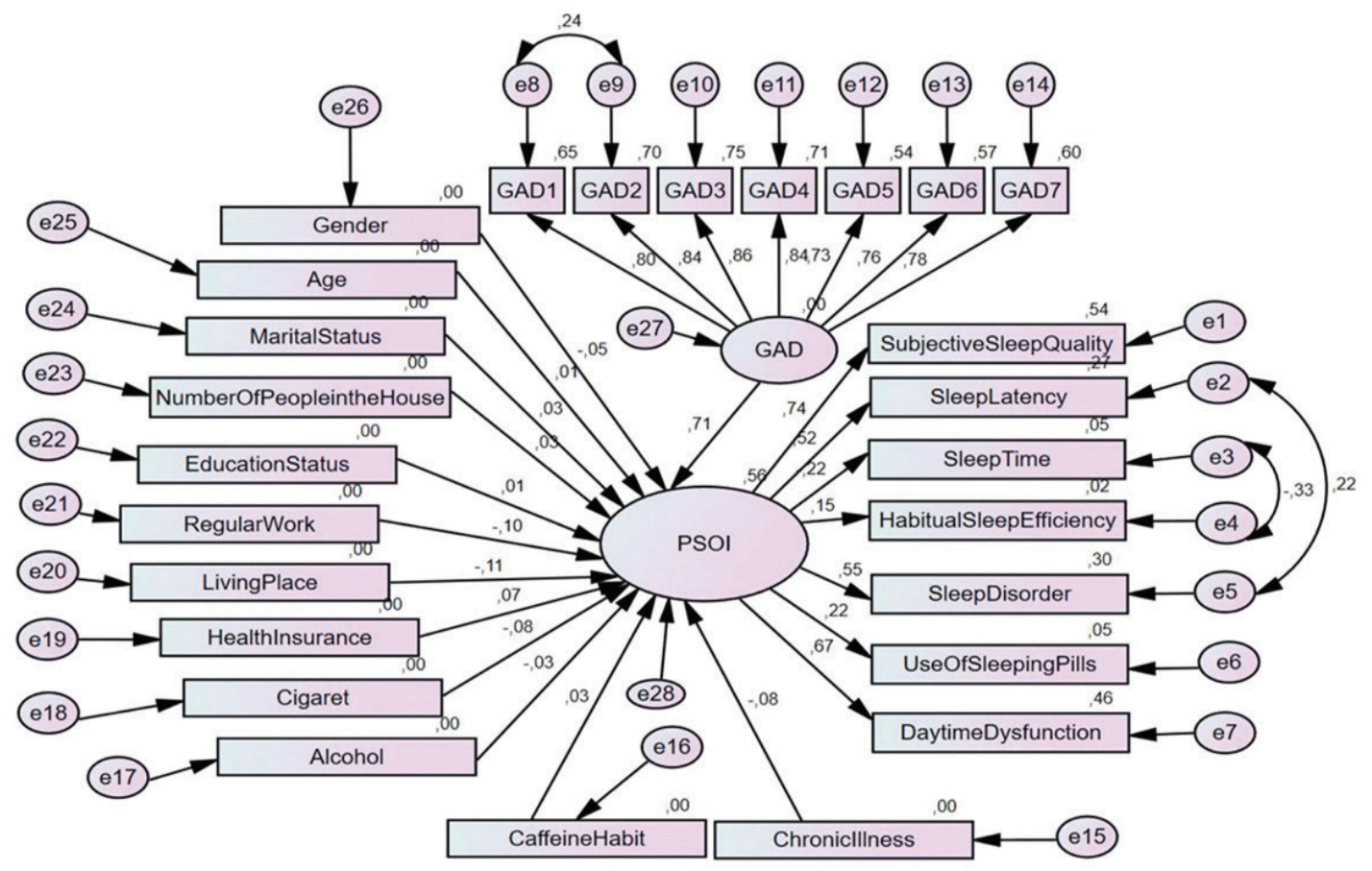

Figure 2. Initial structural equation model predicting factors affecting sleep quality

PSQI: Pittsburgh Sleep Quality index, GAD: Generalized anxiety disorder

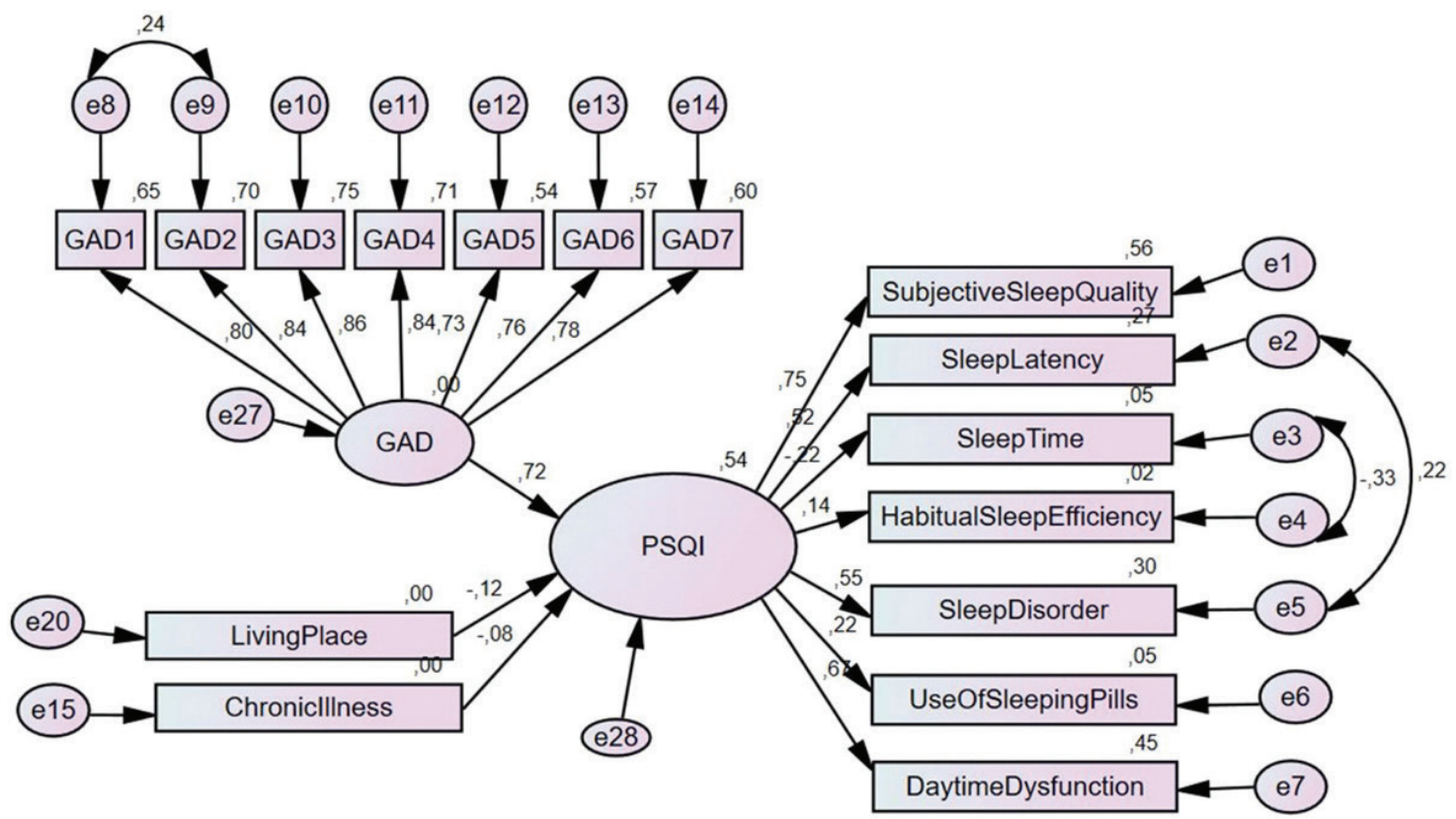

Figure 3. Revised model predicting the factors affecting sleep quality

PSQI: Pittsburgh Sleep Quality index, GAD: Generalized anxiety disorder 
Akkuş et al.

Factors Affecting Sleep Quality in the General Population During the Early COVID-19 Pandemic Phase

\begin{tabular}{|l|l|l|l|l|}
\hline \multicolumn{2}{|l|}{ Table 3. Regression weights of the initial model that describe factors affecting sleep quality } \\
\hline Parameter & & $\begin{array}{l}\text { Implicit } \\
\text { structure }\end{array}$ & $\begin{array}{l}\text { Standardized } \\
\text { regression weight }\end{array}$ & Significance \\
\hline Age & $<---$ & PSQI & 0.008 & 0.870 \\
\hline Gender & $<--$ & PSQI & -0.050 & 0.227 \\
\hline Marital status & $<---$ & PSQI & 0.030 & 0.518 \\
\hline Number of people in the house & $<---$ & 0.034 & 0.423 \\
\hline Educational level & $<--$ & PSQI & 0.828 \\
\hline Regular job & $<---$ & PSQI & 0.009 & 0.051 \\
\hline Place of residence & $<---$ & PSQI & $<0.004$ \\
\hline Health insurance & $<---0.101$ & 0.095 \\
\hline Smoking & $<---$ & PSQI & -0.114 & 0.075 \\
\hline Alcohol use & PSQI & 0.067 & 0.540 \\
\hline Caffeine consumption & PSQI & -0.079 & 0.494 \\
\hline Presence of chronic disease & PSQI & -0.026 & $<0.034$ \\
\hline GAD-7 & $<--$ & PSQI & 0.027 \\
\hline PSQI: Pittsburgh Sleep Quality index, GAD-7: Generalized anxiety disorder-7 & -0.084 & $<0.000$ \\
\hline
\end{tabular}

\section{Discussion}

Studies revealed that during the COVID-19 pandemic, the sleep quality of individuals in the society was negatively affected to varying degrees. In this study, it was observed that sleep quality of the individuals was poor. In their study, Xiao et al. (30) found that individuals had sleep problems during 14-day self-isolation process in China, while Yu et al. (29) stated that during the COVID-19 pandemic, insomnia was at the rate of $29.9 \%$ in individuals in Hubei, China. Stanton et al. (31) determined that $40.7 \%$ of individuals had a negative change in their sleep quality. In their study, Cellini et al. (20) stated that in the second week of the obligation to stay at home, the sleepwake cycle of individuals changed, they went to bed late and woke up late, stayed more in bed, and sleep quality of $52.4 \%$ of them was affected. In their study, Gualano et al. (32) stated that $42.2 \%$ of individuals experienced sleep problems, and $17.4 \%$ experienced severe insomnia. These results support our study. As the GAD-7 score increased, sleep quality decreased, and moderate anxiety was detected. In their study conducted before COVID-19 pandemic, Lauriola et al. (19) stated that anxiety was associated with the severity of insomnia, rather than sleep quality. In the same study, it was stated that trait anxiety and depression were strong predictors of insomnia severity and sleep quality. Similarly, in the studies conducted after the COVID-19 pandemic emerged, a relationship was found between anxiety and sleep quality, and as anxiety increased, sleep quality was affected (20,21,33). As COVID-19 is currently a disease that still negatively affects public health, the anxiety level of individuals living in the society increases. In this study, $42.4 \%$ of the individuals were found to have high anxiety level. In the studies conducted, anxiety was found as $6.33-37.7 \%(34-36)$. Wang stated that anxiety was $70.78 \%$ in individuals under quarantine due to COVID-19 (37). Compared to other studies, it is seen that the rate of anxiety is higher in this study. Although immediate measures were taken after the first
COVID-19 case in Turkey, the uncertainty and unpredictability regarding the disease and its treatment as well as death news reflected on media in other countries might have led to increase in anxiety levels.

Although studies evaluating the sleep quality of women during COVID-19 pandemic are limited, many studies have found that women's anxiety is high (32,38-40). In their study, Liu et al. (33) stated that during COVID-19 pandemic, the severity of symptoms was higher in women. Varshney et al. (41) found that physiological symptoms were at a higher level in women, and women were more psychologically affected. Gerhold (42) stated that in the German population, women were more concerned about COVID-19. In their study conducted in Turkey, Özdin and Bayrak Özdin (13) stated that women had higher levels of depression and anxiety. Wang et al. (43) stated that male gender was not predictive of sleep quality during the COVID-19 outbreak. In this study, there was no difference between males and females in terms of sleep quality. During the COVID-19 pandemic, children, who went to school under normal conditions, were forced to stay at home, education in schools began to be continued at home by means of EBA TV, individuals had to carry out their works from home, women's social activities were affected, the workload of women, who were already primarily responsible for housework in the society, increased.

The number of studies conducted on how sleep quality is affected by age groups during COVID-19 is limited. Wang et al. (43) stated that sleep of individuals over the age of 35 was affected. It is seen that studies compared age variable with anxiety rather than comparing it with sleep during the COVID-19 pandemic. In studies conducted in countries such as Spain and Germany, it was determined that the anxiety level was higher in the elderly $(42,44)$. In countries such as China, England, Australia and India, it was found that young individuals were more psychologically affected during COVID-19, and 
these individuals had a higher level of anxiety $(4,21,31,39,41)$. Determining that the elderly were more affected by this virus may have led to an increase in the anxiety of the elderly in these countries. In this study, no relationship was found between age level and sleep quality during the COVID-19 outbreak. It can be explained by the fact that this study was conducted with individuals under 65 years old.

Wang et al. (43) found low sleep quality in married couples in a study also including healthcare professionals. Voitsidis et al. (38) stated that there was an indirect relationship between loneliness and sleep. Stanton et al. (31) stated that depression, anxiety and stress levels were significantly higher in those who did not have a relationship. In this study, sleep quality does not differ according to marital status.

In this study, sleep quality was not affected by working status. Similarly, Özdin and Bayrak Özdin (13) revealed that postpandemic working status did not affect anxiety, depression and health anxiety. Gualano et al. (32) stated that those who had economic difficulties had more sleep problems. Hacimusalar et al. (40) stated that those whose income decreased after the pandemic had high anxiety levels. In the report published on June $15^{\text {th }}, 2020$, ILO stated that 55 million homeworkers were significantly affected by COVID-19 (45). Reasons such as having to stay at home during the pandemic, the implementation of the rules of social distancing, travel restrictions, reduction of working hours caused some of the business sectors to be affected more, and many people were affected in Turkey.

The sleep quality of individuals living in villages was found to be significantly higher than those living in towns and cities in this study. In a study conducted in Turkey, it was determined that anxiety of those living in metropolitan cities were lower than those living outside metropolitan cities (40). Özdin and Bayrak Özdin (13) stated that depression was more common in those living in urban areas. During this process, the fact that individuals living in the city had to stay at home may have caused a decrease in the exposure to sunlight and affected the quality of sleep. In addition, reasons such as less internet use in village life, maintaining social distance more easily, more use of sunlight and presence of other works outside home may have led to better sleep quality.

Wang et al. (43) found sleep quality of those with comorbidities to be lower. Stanton et al. (31) stated that those with chronic diseases had high levels of depression, anxiety and stress. Özdin and Özdin (13) stated that the health anxiety score was higher in those with chronic diseases. Varshney et al. (41) stated that those with chronic diseases were more affected psychologically. In this study, the sleep quality of those with chronic diseases was adversely affected. Individuals with chronic diseases may have been more affected by the severity of the disease.

\section{Study Limitations}

Insomnia is an important health problem. The studies related to insomnia and affecting factors during the COVID-19 pandemic are limited, and the fact that no study was conducted in the east of Turkey, is the strength of our study. In addition, the limitations of the study are as follows: the data were not collected face-to-face, were self-reported and were limited to only the individuals reached online. Secondly, these data were obtained cross-sectionally, the data of the study belong only to a certain time. In addition, objective methods were not used to evaluate sleep quality and anxiety. Therefore, the data cannot be generalized.

\section{Conclusion}

Anxiety and sleep disturbance are problems that can be easily evaluated by health care professionals and for which measures can be taken in the early period. This study is important in terms of providing feedback to mental health professionals and individuals living in the society and the requirement for continuous and more comprehensive evaluations in the society during the COVID-19 pandemic. Moreover, it has become clear that health and social service providers should be on alert in terms of the symptoms that define anxiety and sleep disturbance in individuals, and in this direction, psychological support providers should be strengthened.

\section{Ethics}

Ethics Committee Approval: This study was carried out in accordance with the principles of Helsinki Declaration. Before the study, permission was obtained from the Ethics Committee of the Faculty of Health Sciences (date: May 6 ${ }^{\text {th }}, 2020$ and issue: 818295502.903/29) and the Ministry of Health.

Informed Consent: Written consent was obtained from the participants

Peer-review: Externally and internally peer-reviewed.

\section{Author Contributions}

Concept: Y.A., S.Ş., Design: Y.A., S.Ş., Data Collection or Processing: Y.A., Y.K., Analysis or Interpretation: Y.A., Y.K., Writing: Y.A., Y.K., A.A.Ü.

Conflict of Interest: No conflict of interest was declared by the authors.

Financial Disclosure: The authors declared that this study received no financial support.

\section{References}

1. Huang C, Wang Y, Li X, Ren L, Zhao J, Hu Y, Zhang L, Fan G, Xu J, Gu X, Cheng Z, Yu T, Xia J, Wei Y, Wu W, Xie X, Yin W, Li H, Liu M, Xiao Y, Gao H, Guo L, Xie J, Wang G, Jiang R, Gao Z, Jin Q, Wang J, Cao B. Clinical features of patients infected with 2019 novel coronavirus in Wuhan, China. Lancet 2020;395:497-506.

2. Republic of Turkey Ministry of Health. Current situation in Turkey from Republic of Turkey Ministry of Health. Last Accessed Date: 19.02.2021. Available from: https://covid19.saglik.gov.tr/TR-66935/ genel-koronavirus-tablosu.html

3. Altena E, Baglioni C, Espie CA, Ellis ], Gavriloff D, Holzinger B, Schlarb $A$, Frase L, Jernelöv S, Riemann D. Dealing with sleep problems during home confinement due to the COVID-19 outbreak: practical recommendations from a task force of the European CBT-I Academy. J Sleep Res 2020;29:e13052. doi: 10.1111/jsr.13052.

4. Rettie $\mathrm{H}$, Daniels J. Coping and tolerance of uncertainty: predictors and mediators of mental health during the COVID-19 pandemic. Am Psychol 2020 Aug 3. doi: 10.1037/amp0000710. Online ahead of print. 
5. Brooks SK, Webster RK, Smith LE, Woodland L, Wessely S, Greenberg $\mathrm{N}$, Rubin G). The psychological impact of quarantine and how to reduce it: rapid review of the evidence. Lancet 2020;395:912-20.

6. Koffman J, Gross J, Etkind SN, Selman L. Uncertainty and COVID-19: how are we to respond? J R Soc Med 2020;113:211-6.

7. Garfin DR, Silver RC, Holman EA. The novel coronavirus (COVID-2019) outbreak: amplification of public health consequences by media exposure. Heal Psychol 2020;39:355-7.

8. Cheng C, Tang CSK. The psychology behind the masks: psychological responses to the severe acute respiratory syndrome outbreak in different regions. Asian J Soc Psychol 2004;7:3-7.

9. Wilder-Smith A, Chiew C), Lee VJ. Can we contain the COVID-19 outbreak with the same measures as for SARS? Lancet Infect Dis 2020;20:e102-7. doi:10.1016/S1473-3099(20)30129-8

10. Schimmenti A, Billieux J, Starcevic V. The four horsemen of fear: An integrated model of understanding fear experiences during the COVID-19 pandemic. Clin Neuropsychiatry 2020;17:41-5.

11. Türkçapar H. Anksiyete Bozukluğu ve Depresyonun Tanısal Illişkileri. Klin Psikiyatr Derg 2004;4:12-6.

12. Ersoy F, Edirne T, Oğuz TF. Birinci Basamakta Anksiyete Bozuklukları 2. Sted 2003;12:326.

13. Özdin S, Bayrak Özdin Ş. Levels and predictors of anxiety, depression and health anxiety during COVID-19 pandemic in Turkish society: the importance of gender. Int J Soc Psychiatry 2020;66:504-11.

14. Çıtak Ş, Pekdemir Ü. An analysis on sleep habits and generalized anxiety levels of individuals during the covid- 19 pandemic. J Fam Couns Educ 2020;5:60-73.

15. Ekiz T, llıman E, Dönmez E. Comparison of health anxiety level and control perception of COVID-19. Uluslararasi Sağlik Yönetimi ve Strat Araştirma Derg 2020;6:139-54.

16. Kang L, Li Y, Hu S, Chen M, Yang C, Yang BX, Wang Y, Hu J, Lai J, Ma X, Chen J, Guan L, Wang G, Ma H, Liu Z. The mental health of medical workers in Wuhan, China dealing with the 2019 novel coronavirus. Lancet Psychiatry 2020;7:e14. doi: 10.1016/ S2215-0366(20)30047-X.

17. Moldofsky H, Patcai J. Chronic widespread musculoskeletal pain, fatigue, depression and disordered sleep in chronic post-SARS syndrome; a case-controlled study. BMC Neurol 2011;11:37.

18. Morin CM, Rodrigue $\mathrm{S}$, Ivers $\mathrm{H}$. Role of stress, arousal, and coping skills in primary insomnia. Psychosom Med 2003;65:259-67.

19. Lauriola M, Carleton RN, Tempesta D, Calanna P, Socci V, Mosca O, Salfi F, De Gennaro L, Ferrara M. A correlational analysis of the relationships among intolerance of uncertainty, anxiety sensitivity, subjective sleep quality, and insomnia symptoms. Int J Environ Res Public Health 2019;16:7-9.

20. Cellini N, Canale N, Mioni G, Costa S. Changes in sleep pattern, sense of time and digital media use during COVID-19 lockdown in Italy. J Sleep Res 2020;29:1-5.

21. Huang Y, Zhao N. Generalized anxiety disorder, depressive symptoms and sleep quality during COVID-19 outbreak in China: a web-based cross-sectional survey. Psychiatry Res 2020;288:1-18.

22. Huang T, Mariani S, Redline S. Sleep irregularity and risk of cardiovascular events: the multi-ethnic study of atherosclerosis. J Am Coll Cardiol 2020;75:991-9.

23. Yazıcıoğlu Y, Erdoğan S. Spss uygulamalı bilimsel araştırma yöntemleri. Detay Yayıncilık, Ankara, 2004;45.

24. Kumar N, Sharma S. Survey analysis on the usage and impact of whatsapp messenger. Glob J Enterp Inf Syst 2017;8:52.

25. Ağargün MY, Kara H AO. The validity and reliability of the pittsburgh sleep quality index. Türk Psikiyatr Derg 1996;7:107-11.
26. Buysse DJ, Reynolds CF, Monk TH, Berman SR, Kupfer DJ. Buysse DJ, Reynolds CF, Monk TH, Berman SR, Kupfer DJ. The Pittsburgh Sleep Quality Index: a new instrument for psychiatric practice and research. Psychiatry Res 1989;28:193-213.

27. Spitzer RL, Kroenke K, Williams JW, Löwe B. A brief measure for assessing generalized anxiety disorder: The GAD-7. Arch Intern Med 2006;166:1092-7.

28. Konkan R, Şenormanci Ö, Güçlü O, Aydin E, Sungur MZ. Validity and reliability study for the Turkish adaptation of the generalized anxiety disorder-7 (GAD-7) scale. Noropsikiyatri Ars 2013;50:53-8.

29. Yu BY-M, Yeung W-F, Lam JC-S, Yuen SC-S, Lam SC, Chung VC-H, Chung K-F, Lee PH, Yan-Yee Ho F. Prevalence of sleep disturbances during COVID-19 outbreak in an urban chinese population: a crosssectional study. Sleep Med 2020;74:18-24.

30. Xiao H, Zhang Y, Kong D, Li S, Yang N. Social capital and sleep quality in individuals who self-isolated for 14 days during the coronavirus disease 2019 (COVID-19) outbreak in January 2020 in China. Med Sci Monit 2020;26:1-8.

31. Stanton R, To QG, Khalesi S, Williams SL, Alley SJ, Thwaite TL, Fenning AS, Vandelanotte C. Depression, anxiety and stress during COVID-19: associations with changes in physical activity, sleep, tobacco and alcohol use in Australian adults. Int J Environ Res Public Health 2020;17:1-13.

32. Gualano MR, Moro G Lo, Voglino G, Bert F, Siliquini R. Effects of covid-19 lockdown on mental health and sleep disturbances in Italy. 2020;17:4779. doi: 10.3390/ijerph17134779

33. Liu N, Zhang F, Wei C, Jia Y, Shang Z, Sun L, Wu L, Sun Z, Zhou Y, Wang Y, Liu W. Prevalence and predictors of PTSS during COVID-19 outbreak in China hardest-hit areas: gender differences matter. Psychiatry Res 2020;287:112921. doi: 10.1016/j.psychres.2020.112921

34. Cullen W, Gulati G, Kelly BD. Mental health in the COVID-19 pandemic. QJM 2020;113:311-2.

35. Su J, Chen X, Yang N, Sun M, Zhou L. Proximity to people with COVID-19 and anxiety among community residents during the epidemic in Guangzhou, China. BJPsych Open 2020;6:e75. doi: 10.1192/bjo.2020.59.

36. Tang F, Liang J, Zhang H, Kelifa MM, He Q, Wang P. COVID-19 related depression and anxiety among quarantined respondents. Psychol Heal 2020;36:164-78.

37. Wang Y, Di Y, Ye J, Wei W. Study on the public psychological states and its related factors during the outbreak of coronavirus disease 2019 (COVID-19) in some regions of China. Psychol Heal Med 2021;26:13-22.

38. Voitsidis P, Gliatas I, Bairachtari V, Papadopoulou K, Papageorgiou G, Parlapani E, Syngelakis M, Holeva V, Diakogiannis I. Insomnia during the COVID-19 pandemic in a Greek population. Psychiatry Res 2020;289:113076. doi: 10.1016/j.psychres.2020.113076

39. Zhang C, Yang L, Liu S, Ma S, Wang Y, Cai Z. Survey of insomnia and related social psychological factors among medical staff involved in the 2019 novel coronavirus disease outbreak. Front Psychiatry 2020;11:306. doi: 10.3389/fpsyt.2020.00306.

40. Hacimusalar $Y$, Kahve AC, Yasar AB, Aydin MS. Anxiety and hopelessness levels in COVID-19 pandemic: a comparative study of healthcare professionals and other community sample in Turkey. J Psychiatr Res 2020;129:181-8.

41. Varshney M, Parel JT, Raizada N, Sarin SK. Initial psychological impact of COVID-19 and its correlates in Indian Community: An online (FEEL-COVID) survey. PLoS One 2020;15:e0233874. doi: 10.1371/ journal.pone.0233874

42. Gerhold L. COVID-19 : risk perception and coping strategies. Results from a survey in Germany. Interdiscip Secur Res Gr 2020;1-11. doi:10.31234/osf.io/xmpk4 
Akkuş et al.

Factors Affecting Sleep Quality in the General Population During the Early COVID-19 Pandemic Phase

43. Wang W, Song W, Xia Z, He Y, Tang L, Hou J, et al. Sleep disturbance and psychological profiles of medical staff and non-medical staff during the early outbreak of COVID-19 in hubei province, China. Front Psychiatry 2020;11:733. doi: 10.3389/fpsyt.2020.00733.

44. Vicario-Merino A, Muñoz-Agustin N. Analysis of the stress, anxiety and healthy habits in the Spanish COVID-19 confinement. Heal Sci J 2020;14:707. doi: 10.36648/1791-809X.14.2.707.
45. International Labour Organization. Impact of the COVID-19 crisis on loss of jobs and hours among domestic workers. 2020;1-10. Available from: https://coronavirus.jhu.edu/ 